REGULAR PAPER

Running Author: $\mathrm{HIRSCH}$

\title{
In the wake: Interpreting care and global health through Black geographies
}

\author{
Liioba A. Hirsch 1,凶
}

Email lioba.hirsch.15@ucl.ac.uk

\section{AQ1 \\ AQ2}

1 Department of Geography, University College London, London, UK

\section{Correspondence}

Lioba A. Hirsch

Email: lioba.hirsch.15@ucl.ac.uk

Building on Black geographies and Black studies, this paper offers critical theoretical reflections on global health interventions in postcolonial societies. Drawing on the work of Christina Sharpe, Katherine McKittrick, and Frantz Fanon I suggest that an epistemic approach rooted in Black studies can offer a novel approach to the study of global health interventions, one that centres Black life, which has long been the subject of colonial violence in medical emergencies. I argue that, given the past history of colonialism and medicine, such an approach is warranted if we seek to decolonise the study and practice of global health interventions. By offering what I call "geographies of the wake," I focus on care's spatial and political entanglements with violence. I make mention of the initial refusal by Sierra Leoneans to seek care in Ebola Treatment Centres and Holding Units and illustrate the spatial aftermath of colonialism and slavery by offering a brief history of one site long associated with care. I ask that this be read as an analytical opening to, not a comprehensive explanation of, Black geographies, global health and medical care.

\section{Graphical Abstract}

Building on Black geographies and Black studies, this paper offers critical theoretical reflections on global health interventions in postcolonial societies. Drawing on qualitative research conducted on the 2014-2016 Ebola epidemic in Sierra Leone, the paper argues that an epistemic approach rooted in Black studies can offer an analytical opening to studying epidemic responses in the wake of past colonial entanglements of violence and care. 


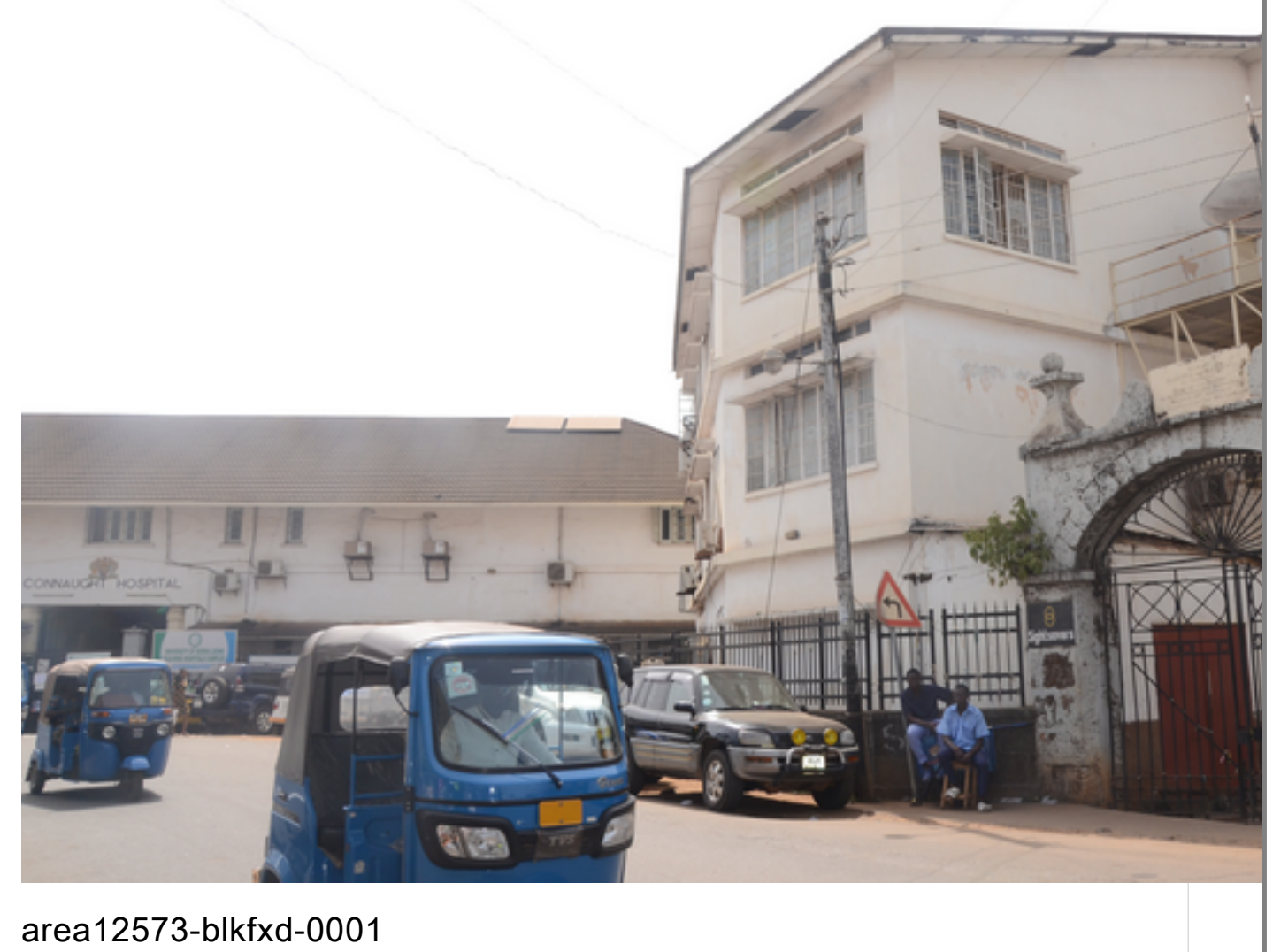

Accepted: 29 June 2019

\section{Keywords}

Black geographies; care; colonialism; Ebola; place; Sierra Leone;

\section{INTRODUCTION}

An extensive literature considers the colonial origins of medicine and the many ways in which medicine and the colonial enterprise have interacted with one another (e.g., Arnold, 1986; Bashford, 2004; Lock \& Nguyen, 2010; Redfield, 2012; Sheller, 2013). A growing literature on critical geographies of global health (e.g., Brown et al., 2012; Ingram, 2013; Taylor, 2016) urges us to "explore multiple temporalities and spatialities, including imperial and colonial historical geographies" (Brown et al., 2012, p. 1183).

Emerging from my research on the 2014-2016 international Ebola response to in Sierra Leone, I offer some theoretical reflections on decolonising global health interventions in a formerly colonised society. Overall my argument draws on Black studies in order to rethink geographies of global health and care. Specifically, I consider how Sharpe's (2016) concept of "the wake" and McKittrick's (2011) "black sense of place" offer new insights into the afterlife of the colonial remains in which the international Ebola response took place. Drawing on Frantz Fanon's (1965) writings 
on the violent encounter between colonialism and medicine, I propose that Black studies offer a unique approach that supplements existing analyses of the 2014-2016 Ebola response in Sierra Leone. Such an approach can ultimately contribute to the epistemic decolonisation of geographies of care and global health. Although they emerge from fieldwork, my reflections are theoretical in nature and I aim in this paper to be merely suggestive.

By drawing on Black studies scholars I aim to contribute to broader discussions around epistemic and practical decolonisation. Recent calls to decolonise geographical knowledges (Esson et al., 2017; Noxolo, 2017) have been echoed by institutions concerned with health and medical sciences (UCL, 2018; Wellcome Collection, n.d.), but as Esson et al. (2017) and Noxolo (2017) point out, projects of epistemic decolonisation are incomplete if they do not extend to the realm of practice. While Spencer (2015) has taken up the task of contextualising the places in which medical care materialises historically, I draw on my research to consider two separate phenomena: the reluctance to seek care and the colonial history of a caregiving site that was involved in the Ebola epidemic. I suggest that building on Sharpe's (2016) concept of "the wake," which explores Black life and death in the wake of slavery and colonialism, the reluctance to seek care can be examined using an approach rooted in Black studies. It can thereby extend existing analyses of the Ebola epidemic, which take the structural, social and political reality of care provision in Sierra Leone into account, but which do not engage critically with the legacies of slavery and colonialism and their afterlives (for a thorough account of the Sierra Leonean Ebola epidemic's local response see Richards, 2016). A historical inquiry into a former colonial hospital, as Joseph et al. (2013) have shown with regards to post-asylum geographies, can highlight what spatial and nominal references remain, what links buildings to their colonial past, and what "strategic forgetting" or "selective remembrance" (Joseph et al., 2013) people engage in to make sense of the caregiving site. I call this spatial approach to colonial and slave-trading remains "geographies of the wake."

I argue in light of this discussion that Black geographies can be instrumental in decolonising geographies of care and global health in that they centre non-European experiences and offer a non-linear understanding of time, both of which respond to the decolonial imperative of problematising coloniality (e.g., Maldonado-Torres, 2011). Such a critique is especially necessary in postcolonial contexts, such as Sierra Leone, where medical care has been a justification for political and cultural domination.

Christina Sharpe's (2016) book In the wake considers the afterlife of slavery as something around which contemporary Black life and death is necessarily structured and to which it must respond. By placing global health interventions in Sierra Leone "in the wake," this paper responds to decolonial and postcolonial imperatives to reconsider how the past is present, both in and among formerly colonised and colonising populations. This decolonial challenge is also taken up by Black geographies, which advocate for an understanding of landscapes as temporally unhinged. In this paper I suggest that medical care during the international Ebola response can be interpreted as still being structured around the remains of slavery and colonialism and that this perspective places the reluctance of many Sierra Leoneans to seek care in a new light. " "The wake" manifests here as a spatial regime as much as a temporal one. 
Tracing the histories of care in a specific geographical location, a corner of Freetown in this case, offers opportunities to view the longevity and persistence of "imperial debris" (Stoler, 2013) both in terms of remaining colonial architectures and the continued presence of British medical expertise. It also highlights the humanitarian and health-specific mobilities that have contributed to the present making of Freetown. Following Raghuram et al.'s (2009) postcolonial analyses of geographies of care and responsibility, I suggest that, in the case of Freetown, contemporary humanitarian responses to global health "crises" occurred in care spaces marked by colonial and anti-Black violence. The lack of trust exhibited by many Sierra Leoneans at the beginning of the epidemic towards (predominantly white) international healthcare workers and to Sierra Leonean health staff working in "white" hospitals (Lipton, 2017), warrants a deeper reflection on the antiblackness that has shaped spaces of care in Sierra Leone. ${ }^{2}$ I extend these explorations by drawing on Sharpe's (2016) writings on Black care to introduce Black scholarly thought to geographies of care and global health.

The 2014-2016 Ebola epidemic predominantly affected Guinea, Liberia and Sierra Leone. The Sierra Leonean response, organised and implemented through the Ministry of Health and Sanitation, the National Ebola Response Centre, and the Sierra Leone Armed Forces was supported by international agencies, NGOs, and bilateral initiatives. Sierra Leonean healthcare workers, who constituted the bulwark of the response (Richards, 2016), were supported by international medical and non-medical staff from the World Health Organization, Save the Children, or King's Sierra Leone Partnership, to name but a few. Despite their efforts, 3,955 people died from the Ebola virus in Sierra Leone (WHO, 2015a).

\section{AQ3}

My research into the international response to the Ebola outbreak in Sierra Leone was conducted in the UK and Europe between May and November 2017 and also included two field visits to Sierra Leone between May and June 2016 and in March 2019. During the former, I was based at the Sierra Leone Urban Research Centre. During my fieldwork I conducted 45 hour-long in-depth interviews in all three locations. Interviews were conducted with medical and diaspora responders to the epidemic representing a variety of medical and diaspora organisations and networks (i.e., King's Sierra Leone Partnership, UK-Med, the Sierra Leone UK Diaspora Ebola Response Taskforce). Between February and November 2017 I made regular visits to both the National Archives and the Wellcome Trust Archives in London, where I researched colonial disease control in Sierra Leone around the turn of the 20th century. In the archives I used the dates of specific outbreaks as well as the reports of British medical researchers who travelled to Sierra Leone as starting points for my research. My archival research focused on colonial practices of infectious disease control and the discursive construction of Sierra Leone as a diseased place.

\section{LOCATING THE WAKE}

Sharpe (2016) offers an analysis of the aftermath of transatlantic slavery and the structuring power this legacy exercises over Black living and dying in the present. She defines her project as "a theory and praxis of the wake; a theory and a praxis of Black being in diaspora" (Sharpe, 2016, p. 19). For Sharpe (2016), living in the wake means being awake to the anti-Black atmosphere - or antiblackness - that characterises our contemporary world. I argue that Sharpe's anti-Black atmospheres can contribute to 
effectively decolonise global health geographies and interventions in formerly colonised societies. Although she makes reference to the global dimensions of the wake (2016, p. 15), Sharpe largely focuses on the Black diaspora in North America. However, I use "the wake" as the conceptual frame for this paper because, as Ferme (2001) and Shaw (2002) argue, the slave trade has left material and non-material traces in Sierra Leone, from where thousands of enslaved Africans were sold into slavery between the 17th and 19th centuries (Rodney, 1980, pp. 250-251). It is through these traces, which persist in Sierra Leone in spatial and material form, that the past influences the present and it is in light of these traces that I reflect on the 2014-2016 Ebola epidemic in Sierra Leone.

In Freetown, the wake materialises in the place-making power of the slave-trading and colonial past, in the spaces marked by slavery and colonialism, their physical presence, ongoing ruination, or absence influencing our understanding of colonialism's spatial tenacity. I refer to both this place-making power and the (non-)material structures that result from them as "geographies of the wake." Geographies of the wake are geographies of the present. They are part of the continued hold the colonial and slave-trading past has on the spatial and material entanglement of places with that past. Geographies of the wake are geographies of past encounters, framed by violence and Black subjugation in and in relation to Sierra Leone. The contemporary uses to which these structures are put need not replicate or intend to replicate colonial and slave-trading practices in their original form to constitute the wake. Rather, the wake manifests through memorials, through architectural remains, through buildings whose initial function supported colonialism and the slave trade, but whose current usage is largely disassociated from that past.

I now draw on McKittrick's (2011) idea of "a black sense of place" to further explain what I understand by geographies of the wake and to relate them to Black geography. Following her pioneering work on Black geographies, I argue that a "black sense of place" accepts that landscapes are not "comfortably situated in the past, present or future" (McKittrick, 2006, p. 2). As such, geographies of the wake in Sierra Leone engender an understanding of place that oscillates between the anti-Black violence of the past and the postcolonial present in which the Ebola response occurred. McKittrick offers several definitions, but I focus on a "black sense of place" as "a sense of place wherein the violence of displacement and bondage, ... extends and is given a geographic future" (2011, p. 949). While McKittrick (2011), similarly to Sharpe (2016), writes about Black being in the American diaspora, I extend her analysis of how past experiences of anti-Black violence create a present understanding of and relation to place and geography in Sierra Leone. The particular relevance of placing care in the wake comes from the spatial anchoring that entanglements of care and violence have taken in relation to Black life in Sierra Leone. Ultimately, I propose that attention to geographies of the wake enables a critical inquiry into the spatial afterlife of the conflation of care and violence.

In Freetown, the spatial and material present is still shaped by British colonialism. Street names such as Wilberforce Street, Wilkinson Street, or Macaulay Street are but a few examples of the continued nominal presence of British colonial administrators and influencers in Freetown's cityscape. Geographies of the wake thus refer to colonialism as the continuous, largely normalised, reference point around which parts of urban life isare structured. At the same time I propose that awareness of geographies of the wake must include what Sharpe calls "a form of consciousness" 
(2016, p. 14) around the situated and localised experience of colonial and enslaved violence, anchored in landscapes and the built environment. In this paper I want to think the 2014-2016 Ebola response through geographies of the wake. To do so I draw on archival research I conducted on one caregiving site to highlight the historical role that some places of care have played in British colonialism and the preceding slave trade. By introducing geographies of the wake I build on geographical work by, among others, Joseph et al. (2013) and Repo (20198), who have focused their geographical analyses of health on places of care. While I can only broach the topic here, this paper is a call to extend their work to include colonialism's spatial remains.

Placing care in the wake means considering its past proximity to colonial violence in relation to Black (and) Sierra Leonean bodies. It means asking, as Sharpe does:

What happens when we proceed as if we know this, antiblackness, to be the ground on which we stand, the ground from which we attempt to speak, for instance, an 'l' or a 'we' who know, an 'l' or a 'we' who care? (2016, p. 7; emphasis in original)

By placing care in the wake, I acknowledge antiblackness as a constitutive part of the development and reality of care in the colonial and postcolonial world. Postcolonial analyses of care work have emerged within broader geographies of care and responsibility (e.g., Massey, 2004; Raghuram et al., 2009) to carry out similar projects. They question the colonial nature of power dynamics inherent in care work and explore the care deficit left in the global South, due to South-North migrations (Raghuram, 2012). While Sophie Bowlby's (2010, p. 135) contention that geographies of care generally operate under the implicit assumption that care is good takes on specific urgency in the wake, postcolonial geographies of care have so far eschewed an explicit focus on Black geographies. However, Raghuram et al. (2009, p. 10) restate the postcolonial importance of accurately remembering the past in efforts to deliver "responsible and 'care-full' agency."

In Sierra Leone care has long occurred in the context of structural violence through both slavery and colonialism. Indeed, the British presence in Sierra Leone has been framed by colonial administrators in terms of care, first with the establishment of "Freedom Province" by British philanthropists to provide a home for poor Blacks and freed slaves in 1787 and subsequently with the gradual incorporation of the Sierra Leonean territory into a colony (Shaw, 2002). Colonialism too has long been framed as British care for the peoples of Sierra Leone, prompting historian David Olusoga to refer to Sierra Leone as an "outpost of British philanthropic colonialism" (2016, p. 166). When care has been used in the context of and for such violent means against Black people, its contemporary uses need to be critically questioned. Biomedical encounters in the postcolonial world build on uses of care as and for violence. This further complicates the power dynamics between those who give and those who receive care.

\section{CONTEXTUALISING CARE IN THE WAKE}

My attention here is on how global health interventions in formerly colonised societies operate in a landscape that knows the conflation of care and violence I discuss above. Building on Ann Bartos' claim that "responding to care is political" $(2018$, p. 2), I argue 
that, in the wake, a critical spatial exploration of care needs to cautiously engage with places of care to understand practices of care as inherently political. It also needs to understand the effects of these practices.

Fanon's writings on colonialism and medicine help us put care practices into context. Richards (2016) and Nuriddin et al. (2018) have attended to the patient-doctor dynamics of the Ebola response in various ways; Fanon (1965), however, offers a lens of interpretation directly linked to and based on the colonial context in which he operated. Considered an early proponent of decolonial and postcolonial theory and, importantly for this paper, a trained doctor and medical chief at the psychiatric hospital in Blida (Algeria) during the Algerian Liberation War, Fanon examined the psychological impact of racism and colonialism for both coloniser and colonised. In $A$ dying colonialism he states "in the colonies, the doctor is an integral part of colonisation, of domination, of exploitation” (1965, p. 134).

One of the main themes he explores, and a topic which became vitally important during the 2014-2016 Ebola epidemic, is people's reluctance to be hospitalised in colonial hospitals. During the Ebola epidemic the hesitation to seek care significantly hampered early response efforts (Richards, 2016; WHO, 2015b). According to Fanon (1965, p. 124), the reluctance to give oneself over to the care of European doctors was always linked to the colonial violence in which these doctors necessarily operated. He writes: "The colonised not only refused to send the patient to the hospital, but refused to send him to the hospital of the whites, of strangers, of the conqueror" (1965, p. 125). The hospital, in Fanon's writings, is not a place of care, but one of suspicion and violence. My point here is not to discount the societal and structural factors that led to people's reluctance to seek care in Sierra Leone. The high rate of nosocomial infections at the beginning of the epidemic, historically anchored mistrust of foreign health workers, knowledge of government corruption, and the high mortality rate were all understandable reasons why people refused to seek care (Walsh \& Johnson, 2018). Rather, I here seek to show that an engagement with Black studies and a focus on colonial violence can contribute to a fuller understanding of the less visible dynamics that shaped the Ebola response. In light of the violent entanglements between colonialism and medicine in formerly colonised societies and in light of the psychological consequences of racism and colonialism that Fanon explores, should we not consider the politics of global health interventions from a Black studies approach in order to disentangle care from its violent past, especially when it occurs in places of care marked by colonial violence?

Medical care during the Ebola epidemic in Sierra Leone was provided by a multitude of institutional and individual actors, taking various forms and drawing on diverse understandings of health and disease. As Richards (2016) shows, international responders' failure to take Sierra Leonean knowledge into account led to misguided decision-making and reduced the response's effectiveness. I use the lens of geographies of the wake to look specifically at the site now occupied by Connaught Hospital to illustrate the spatial conflation of violence and care and the possibilities of adopting a "black sense of place" (McKittrick, 2011).

Connaught Hospital, Freetown's main referral hospital, played an important role during the Ebola response. While the hospital remained under Sierra Leonean management, King's Sierra Leone Partnership (KSLP), a medical NGO operating in Freetown since 2013, ran the Ebola holding unit in an exemplary, thoughtful way. 
Between May 2014 and January 2015, Connaught Hospital and the satellite Ebola Holding Units that KSLP set up across Freetown saw more than a third of all Ebola cases in Western Area Urban and Rural, the administrative districts that comprise and border Freetown (KSLP, n.d.).

\section{AQ4}

Following Stoler and in line with McKittrick (2011), I suggest that Connaught's site is an "occluded, unexpected site in which earlier imperial formations have left their boldfaced or subtle traces" (2013, p. 3). The site on which Connaught Hospital is located, on the Northern edge of Freetown, wedged between the city and the Atlantic Ocean, has long been a place in which care and violence have coexisted. In the period from 1690 to 1800 between 440,000 and 660,000 enslaved Africans were shipped to the Americas from the coast of Sierra Leone (Rodney, 1980, pp. 250-251; Shaw, 2002, p. 29). The majority of slave ships sailed under a British flag (Slave Voyages - The Trans-Atlantic Slave Trade Database, 2013). With the abolition of the British slave trade in 1807, the British navy patrolled the coast of West Africa, captured slave ships, and brought freed slaves to King's Yard, an enclosed space on the site that Connaught Hospital now occupies. In King's Yard, freed Africans were registered and medically examined. If necessary, they were cared for in the adjoining Royal Hospital and Asylum (Olusoga. 2016, pp. 309-310) and at times isolated there to protect the health of the colony. ${ }^{3}$ Today, one of two original gates marking the geographical boundaries of King's Yard remains. An inscription at the top of the gate references the Royal Hospital and Asylum that was constructed to provide care to "Africans rescued from slavery by British valour and philanthropy" and thereby attests to the history of British care at this site. King's Yard forms a spatial and political marker of the transition from enslavement to resettlement in Sierra Leone. However, resettlement often entailed unpaid labour for up to seven years under the so-called "apprenticeship system" (Olusoga, 2016, p. 314). Here physical and structural violence both precedes and follows care (Figure 1 ).

AQ5 


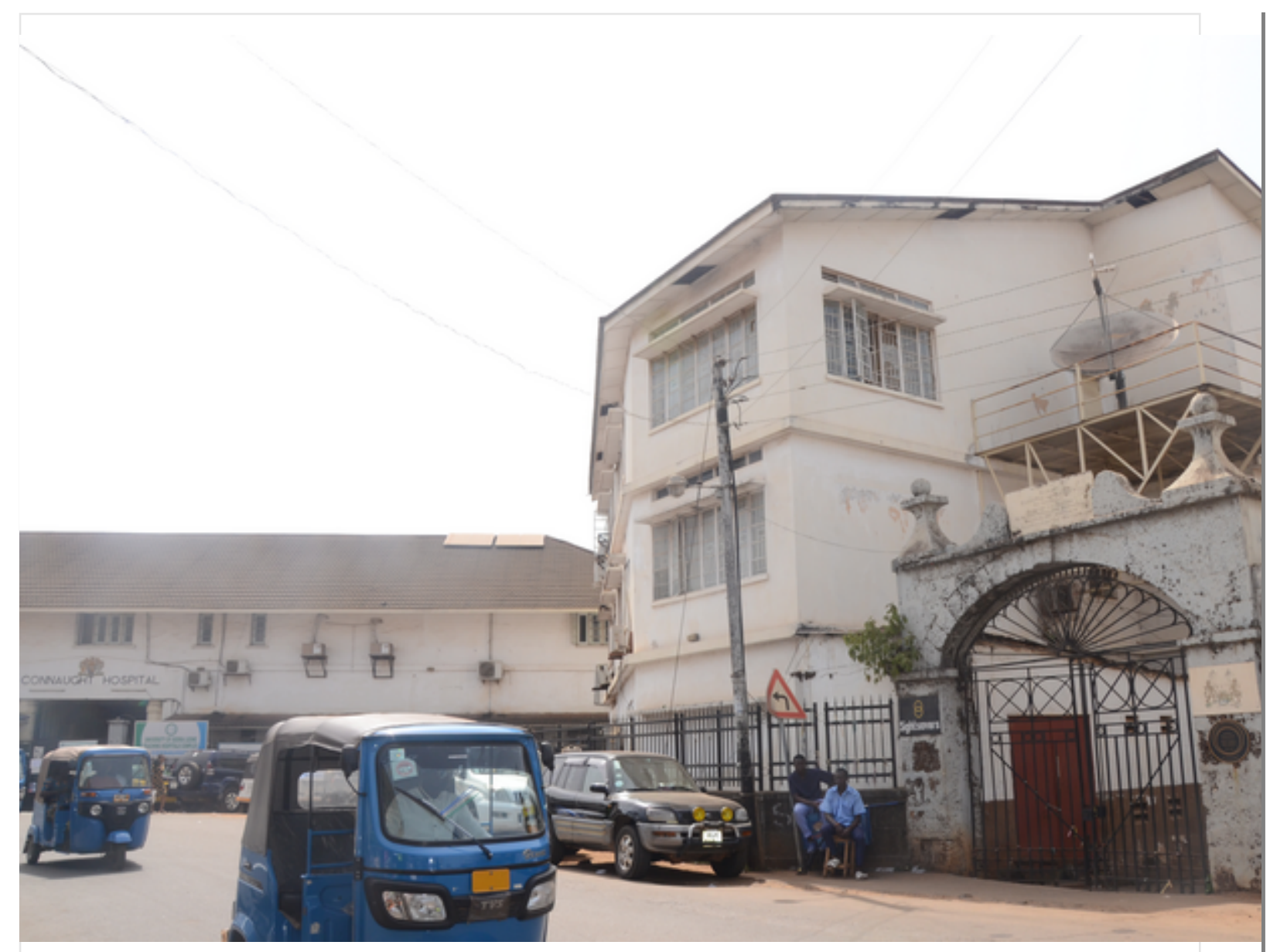

Fig. 1 Connaught Hospital and King's Yard Gate.Source: Photography by author.

The same site later became the location of Freetown's Colonial Hospital in which care was racially segregated (Colonial Office, 1910-1913). The Royal Hospital and Asylum was torn down in the early 20th century. A 1913 Annual Medical Report on Sierra Leone describes the plans for its demolition and for the subsequent construction of Connaught Hospital, which was built on this site in the 1920s (Colonial Office, 1910-1913, p. 97; Colonial Office, 1906-1924, p. 21). Today, the only physical remains of the histories of enslavement, liberation, and colonialism at this site are reminders of British care: Connaught Hospital and the gate to King's Yard.

Following Stoler (2013), I argue that the structures and names that have been preserved at this site after colonial domination (Connaught Hospital) and those that are destroyed, forgotten (the Royal Hospital and Asylum, the Colonial Hospital), or left to ruin (the gate) offer insights into the strategic tenacity of colonialism's spatial and conceptual afterlife. In Sierra Leone, geographies of the wake point to the physical remains of slavery and colonialism in places of care. Cognisance of the remains of slavery and colonialism on Connaught's site offers an opportunity to reflect on the sometimes intangible nature of Black geographies and an opportunity to link this knowledge to analyses of care, thereby centring a Black understanding of care and space.

Interpreting care and global health interventions in light of the wake suggests a sense 
of place attuned to the anti-Black violence that has shaped medical care in the colonial encounter in Sierra Leone and throughout the colonial world. Building on Stoler (2013), Fanon (1965), Sharpe (2016), and McKittrick (2011), I propose that in the case of Sierra Leone imperial debris needs to be uncovered if we want to contribute to a just and historically aware examination of health and medical interventions. Making sense of geographies of global health and care in formerly colonised societies requires a consciousness of the versatile continuity of antiblackness today and an acceptance that we live and care in the wake.

\section{CONCLUSION}

An exploration of geographies of the wake examines how entanglements of care and violence leave their traces in particular places of care. As such, greater attention to geographies of the wake can contribute to both theoretical and practical decolonisation. If care is to be divorced from violence, emergency medical interventions and the scholarly projects that attend to them must work to centre Black life and recognise the pervasive reality of antiblackness.

The study of places of care should encompass an understanding of the colonial past that has shaped these places and, in many cases, led to their construction. The possibility that in the wake, as in colonial times, what are for some neutral places of care might be resisted and viewed with suspicion by others should be considered in geographies of care and global health.

Black geographies thus offer an approach to the study of care and global health that is conscious of the epistemic, political, and spatial hold of past and present anti-Black violence in particular places. By considering care in one such site and providing context to the colonial history of refusing care, I have aimed to showcase the possibilities of integrating Black studies and perspectives into the geographical study of global health and care.

\section{ACKNOWLEDGEMENTS}

I would like to thank Dr Alan Ingram for his continued support and advice throughout the writing of this paper. I would also like to thank Dr Aidan Mosselson for his advice during the revision process.

\section{AQ6}

\section{DATA ACCESSIBILITY}

All data has been anonymised and is stored securely.

\section{Findinotes}

${ }^{1}$ I do not seek here to explain why people were reluctant to seek care, rather I aim to interpret the socio-historical context in which this reluctance took place.

${ }^{2}$ The issue of a lack of trust in the healthcare system and in foreign medical staff came up repeatedly during my research. For a discussion of trust during the Ebola epidemic in Sierra Leone, see for instance Nuriddin et al. (2018) and Walsh and Johnson (2018).

${ }^{3}$ Interview with Sierra Leonean historian Dr Sylvanus Spencer in Freetown, 30 May 2016.

\section{Funding Information}

\begin{tabular}{|l|l}
\hline Heinrich-Böll Foundation & P121536
\end{tabular}




\section{REFERENCES \\ AQ7}

Arnold, , D. (1986). Cholera and colonialism in British India. . Past and Present, $113,118-151$.

Bartos, , A. E. (2018). Relational spaces and relational care: Campus sexual violence, intimate geopolitics and topological polis. . Area . Advance online publication. https://doi.org/10.1111/area.12449

Bashford, , A. (2004). Imperial hygiene: A critical history of colonialism, nationalism and public health. Houndsmills [England]: New York, NY: Palgrave Macmillan.

Bowlby, , S. (2010). Thoughts on 'geographies of care' prompted by reading Annemarie Mol's The logic of care: Health and the problem of patient choice. . Area , 42, 135-136. https://doi.org/10.1111/j.1475-4762.2009.00935_1.x

Brown, , T., Craddock, , S., \& Ingram, , A. (2012). Critical interventions in global health: Governmentality, risk, and assemblage. . Annals of the Association of American Geographers , 102, 1182-1189. https://doi.org/10.1080 /00045608.2012.659960

Colonial Office. (1906-1924). Sierra Leone: Colonial Reports. The National Archives Reference Collection (CO1071/323). The National Archives, Kew.

Colonial Office. (1910-1913). Administration report. The National Archives Reference Collection (CO270/45). The National Archives, Kew.

Esson, , J., Noxolo, P., Baxter, R., Daley, P., Byron, M. (2017). The 2017 RGS- IBG chair's theme: Decolonising geographical knowledges, or reproducing coloniality?. Area , 49, 384-388. https://doi.org/10.1111 AQ8 /area.12371

Fanon, , F. (1965). A dying colonialism. London, UK: Writers and Readers.

Ferme, , M. C. (2001). The underneath of things: Violence, history, and the everyday in Sierra Leone. Berkeley, CA: University of California Press.

Ingram, , A. (2013). After the exception: HIVIAIDS beyond salvation and scarcity. . Antipode , 45, 436-454. https://doi.org/10.1111/j.1467-8330.2012.01008.x

Joseph, , A., Kearns, , R., \& Moon, , G. (2013). Re-imagining psychiatric asylum spaces through residential redevelopment: Strategic forgetting and selective remembrance. . Housing Studies , 28, 135-153. https://doi.org/10.1080 /02673037.2013.729270

King's Sierra Leone Partnership. (2017). Our work - King's Sierra Leone partnership. Retrieved from http://kslp.org.uk/about-kings-sierra-leone- 
Lipton, , J. (2017). 'Black' and 'white' death: Burials in a time of Ebola in Freetown, Sierra Leone. . Journal of the Royal Anthropological Institute , 23, 801-819. https://doi.org/10.1111/1467-9655.12696

Lock, , M. M., \& Nguyen, , V.-K. (2010). An anthropology of biomedicine. Chichester, UK: Wiley-Blackwell.

Maldonado-Torres, , N. (2011). Thinking through the Decolonial turn: Postcontinental interventions in theory, philosophy, and critique - An introduction. .

AQ10 Transmodernity , 1, xxxx-xxxx.

Massey, , D. (2004). Geographies of responsibility. . Geografiska Annaler: Series B, Human Geography , 86, 5-18. https://doi.org/10.1111 /j.0435-3684.2004.00150.x

McKittrick, , K. (2006). Demonic grounds Black women and the cartographies of struggle. Minneapolis, MN: University of Minnesota Press.

McKittrick, , K. (2011). On plantations, prisons, and a black sense of place. . Social \& Cultural Geography , 12, 947-963. https://doi.org/10.1080 $/ 14649365.2011 .624280$

Noxolo, , P. (2017). Introduction: Decolonising geographical knowledge in a colonised and re-colonising postcolonial world. . Area , 49, 317-319. https://doi.org/10.1111/area.12370

Nuriddin, , A., Jalloh, , M. F., Meyer, , E., Bunnell, , R., Bio, , F. A., Jalloh, , M. B., Dengeh, , P., Hageman, , K. M., Carroll, , D. D., Conteh, , L., \& Morgan, , O. (2018). Trust, fear, stigma and disruptions: Community perceptions and experiences during periods of low but ongoing transmission of Ebola virus disease in Sierra Leone, 2015. . BMJ Global Health , 3, e000410. https://doi.org /10.1136/bmjgh-2017-000410

Olusoga, , D. (2016). Black and British: A forgotten history. London, UK: Macmillan.

Raghuram, , P. (2012). Global care, local configurations - challenges to conceptualisations of care. . Global Networks , 12, 155-174. https://doi.org /10.1111/j.1471-0374.2012.00345.x

Raghuram, , P., Madge, , C., \& Noxolo, , P. (2009). Rethinking responsibility and care for a postcolonial world. . Geoforum , 40, 5-13. https://doi.org/10.1016 /j.geoforum.2008.07.007

Redfield, , P. (2012). The unbearable lightness of ex-pats: Double binds of humanitarian mobility. . Cultural Anthropology , 27, 358-382. https://doi.org /10.1111/j.1548-1360.2012.01147.x

Repo, , V. (2018). Spatial control and care in Finnish nursing homes. . Area , 
Richards, , P. (2016). Ebola: How a people's science helped end an epidemic. London, UK: Zed Books.

Rodney, , W. (1980). A history of the upper Guinea Coast, 1545-1800. New York, NY: Monthly Review Press.

Sharpe, , C. E. (2016). In the wake: On Blackness and being. Durham, NC: Duke University Press.

Shaw, , R. (2002). Memories of the slave trade: Ritual and the historical imagination in Sierra Leone. Chicago, IL: University of Chicago Press.

Sheller, , M. (2013). The islanding effect: Post-disaster mobility systems and humanitarian logistics in Haiti. . Cultural Geographies , 20, 185-204. https://doi.org/10.1177/1474474012438828

Slave Voyages - The Trans-Atlantic Slave Trade Database. (2013). Search the Voyages Database. Retrieved from http://slavevoyages.org/voyage/search

Spencer, S. (2015). 'Invisible Enemy' - Translating Ebola Prevention and Control Measures in Sierra Leone. In U. Engel \& R. Rottenburg (Eds.), Adaptation and Creativity in Africa: Technologies and significations in the making of order and disorder (pp. 1-19). Leipzig and Halle: German Research AQ111 Foundation.

Stoler, , A. L. (Ed.) (2013). Imperial debris: On ruins and ruination. Durham, NC: Duke University Press.

Taylor, , S. (2016). Making space for restoration: Epistemological pluralism within mental health interventions in Kinshasa, Democratic Republic of Congo. . Area , 49, 342-348. https://doi.org/10.1111/area.12322

UCL. (2018, March 26). Decolonising the medical curriculum. Retrieved from https://www.ucl.ac.uk/culture/whats-on/decolonising-medical-curriculum

Walsh, , S., \& Johnson, , O. (2018). Getting to zero: A doctor and a diplomat on the Ebola frontline. London, UK: Zed Books.

Wellcome Collection. (n.d.). Decolonising health. Retrieved from https://wellcomecollection.org; https://wellcomecollection.org/events /Wn3LzSoAACsAIcv4

WHO. (2015a). Ebola situation report. Retrieved from http://apps.who.int /iris/bitstream/handle/10665/191299

lebolasitrep_28Oct2015_eng.pdf;jsessionid=CA9AA4F0509671337A56382C391F4D9E

WHO. (2015b). WHO | Ebola in Sierra Leone: A slow start to an outbreak that eventually outpaced all others. Retrieved from http://www.who.int/csr/disease 
